Article

\title{
Cooperative Effects in Weak Interactions: Enhancement of Tetrel Bonds by Intramolecular Hydrogen Bonds
}

\author{
Cristina Trujillo ${ }^{1}{ }^{(0)}$, Ibon Alkorta ${ }^{2}$ (D) José Elguero $^{2}$ and Goar Sánchez-Sanz ${ }^{3,4, *}$ \\ 1 Trinity Biomedical Sciences Institute, School of Chemistry, The University of Dublin, Trinity College, \\ Dublin 2, Ireland; trujillc@tcd.ie \\ 2 Instituto de Química Médica, CSIC, Juan de la Cierva, 3, E-28006 Madrid, Spain; ibon@iqm.csic.es (I.A.); \\ iqmbe17@iqm.csic.es (J.E.) \\ 3 Irish Centre of High-End Computing, Grand Canal Quay, Dublin 2, Ireland \\ 4 School of Chemistry, University College Dublin, Belfield, Dublin 4, Ireland \\ * Correspondence: goar.sanchez@ichec.ie; Tel.: +353-1-524-1608 (ext. 47)
}

Received: 3 December 2018; Accepted: 9 January 2019; Published: 16 January 2019

check for updates

\begin{abstract}
A series of silyl and germanium complexes containing halogen atoms (fluorine and chlorine atoms) and exhibiting tetrel bonds with Lewis bases were analyzed by means of Møller-Plesset computational theory. Binding energies of germanium derivatives were more negative than silicon ones. Amongst the different Lewis bases utilized, ammonia produced the strongest tetrel bonded complexes in both $\mathrm{Ge}$ and $\mathrm{Si}$ cases, and substitution of the $\mathrm{F}$ atom by $\mathrm{Cl}$ led to stronger complexes with an ethylene backbone. However, with phenyl backbones, the fluorosilyl complexes were shown to be less stable than the chlorosilyl ones, but the opposite occurred for halogermanium complexes. In all the cases studied, the presence of a hydroxyl group enhanced the tetrel bond. That effect becomes more remarkable when an intramolecular hydrogen bond between the halogen and the hydrogen atom of the hydroxyl group takes places.
\end{abstract}

Keywords: non-covalent interactions; MP2; binding energy; intramolecular hydrogen bonds; tetrel bonds

\section{Introduction}

One of the major achievements in contemporary chemistry was the introduction by Jean-Marie Lehn of supramolecular chemistry [1]. According to Vögtle "In contrast to molecular chemistry, which is predominantly based upon the covalent bonding of atoms, supramolecular chemistry is based upon intermolecular interactions, i.e., on the association of two or more building blocks, which are held together by intermolecular bonds". Today, these intermolecular bonds are called weak interactions regardless of whether they are intra or intermolecular. There are numerous weak interactions, also known as non-covalent interactions, and they have been shown to be of the upmost importance across different domains including biology, chemistry and material science [2]. These non-covalent interactions has been categorised based on the interacting atoms involved: hydrogen bonds [3,4], halogen bonds [5], hydride bonds [6,7], pnictogen bonds [8-13], chalcogen interactions [14-18] and tetrel bonds [19-22]. The latter, tetrel bonds, are defined, analogous to halogen bonds, as interactions between electron donors and tetrel atoms ( $\mathrm{C}, \mathrm{Si}$ and $\mathrm{Ge})$, in which the tetrel atom acts as an electron acceptor, usually through an electron-deficient outer lobe of a p orbital, called a $\sigma$-hole [23] by Politzer and Murray [24-26], which is formed in the tetrel atom, especially when the atom bonded to the tetrel is highly electronegative. It has also been shown that interactions through $\sigma$-holes are mainly driven by the electrostatic interaction term [27-38]. 
Related to this topic is cooperativity, usually intermolecular (allosteric), but also, although much less studied, intramolecular [39]. There are two relevant papers. Berryman et al. reported the synthesis and anion-binding properties of receptor $\mathbf{1}$ (2,6-bis(4-ethynylpyridinyl)-4-fluoroaniline) which can act as a halogen donor, trapping a wide variety of anions $\left(\mathrm{Cl}^{-}, \mathrm{Br}^{-}, \mathrm{I}^{-}, \mathrm{SCN}^{-}, \mathrm{NO}_{3}{ }^{-}, \mathrm{HSO}_{4}{ }^{-}, \mathrm{H}_{2} \mathrm{PO}_{4}{ }^{-}\right.$ and $\mathrm{ReO}_{4}^{-}$) [40] (Scheme 1). The presence of intramolecular $\mathrm{N}-\mathrm{H} \cdots$ I hydrogen bonds (HBs) increases the strength of the I $\cdots$ anion halogen bonds (XBs).

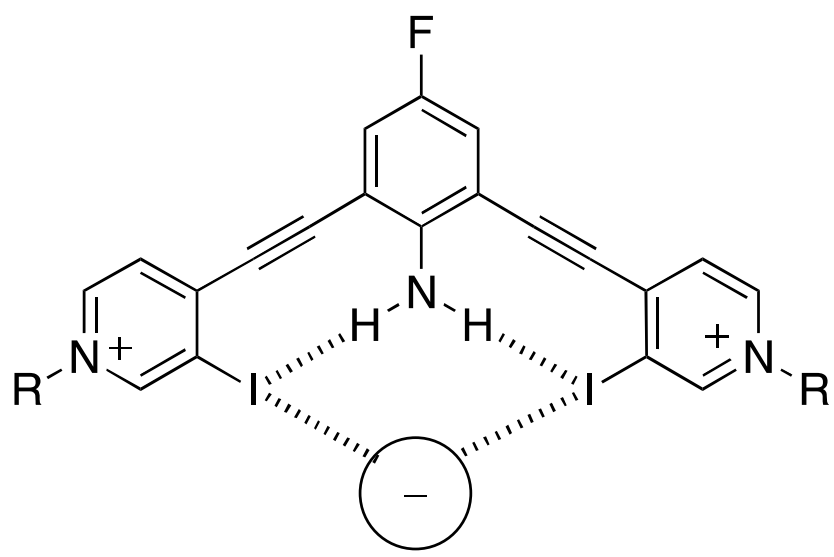

1

Scheme 1. Schematic description of 2,6-bis(4-ethynylpyridinyl)-4-fluoroaniline interacting with anions.

Ho and co-workers described how the $\sigma$-hole responsible for the $\mathrm{XB}$ is substantially increased by an intramolecular HB [41]. The model they selected was 2-halophenol (2) that can exist as two limit conformations (Scheme 2), the anti one without HB and the syn one with an intramolecular HB (IMHB).

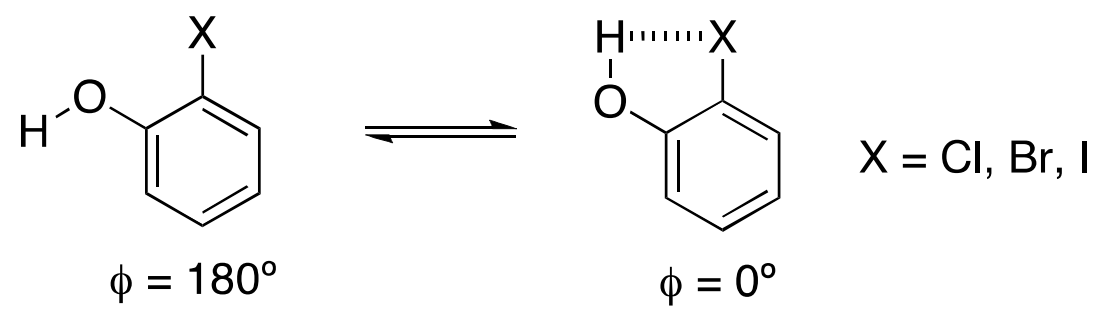

\section{2}

Scheme 2. The two conformers of 2-halophenol.

For each $X$, they calculated the electrostatic potential map as a function of the torsion angle $\phi$. They found that the positive zone increases considerably when the torsion angle approaches $0^{\circ}$, i.e., when there is an IMHB.

In the present article, the effect of the intramolecular hydrogen bond in fluorosilyl and fluorogermanium derivatives and their abilities as tetrel bond donors is studied (Scheme 3). The following notation will be used to label the complexes studied throughout the manuscript: $\mathrm{nTX}_{\mathrm{a}} \mathrm{Z}: \mathrm{LB}$, where " $\mathrm{n}$ " stands for the two types of carbon backbone (1=allyl, $2=$ phenyl), "T" stands for the tetrel atom ( $\mathrm{Si}$ or $\mathrm{Ge}$ ), "Z" indicates whether the complex exhibits, or does not exhibit, an intramolecular hydrogen bond (IMHB or none), "a" indicates the presence of an OH group in the molecule (hydroxyl=H) or not (allyl=A). Finally, LB stands for the Lewis Base involved $\left(\mathrm{NH}_{3}, \mathrm{H}_{2} \mathrm{O}\right.$ or $\left.\mathrm{HCN}\right)$. For example, $1 \mathrm{GeCl}_{\mathrm{A}}{ }^{\mathrm{IMBH}}: \mathrm{NH}_{3}$ corresponds to an allylchlorogermanium derivative interacting with ammonia in which the $\mathrm{OH}$ group is present and forming an intramolecular hydrogen bond. The short notation 1TX:LB will be used to refer the whole complex family. 
<smiles>[Y][I+]([B])([B])C=C</smiles>

$1 T X_{A}: L B$<smiles>[Y][Y]([H])([B])c1ccccc1</smiles>

$2 \mathrm{TX}_{\mathrm{A}}: \mathrm{LB}$<smiles>[X][Y]([H])(Br)/C=C\O</smiles>

$1 T X_{H}: L B$<smiles>[Y][Y]([H])([B])c1ccccc1O</smiles>

$2 \mathrm{TX}_{\mathrm{H}}: \mathrm{LB}$<smiles>[X][I+]1([13CH3])C=CO[CH]O1</smiles><smiles>[Y10][13CH3]</smiles>
$\mathrm{T}=\mathrm{Si}, \mathrm{Ge}$ $\mathrm{X}=\mathrm{F}, \mathrm{Cl}$ $\mathrm{LB}=\mathrm{NH}_{3}, \mathrm{H}_{2} \mathrm{O}, \mathrm{HCN}$

Scheme 3. Schematic representation of the nTX:LB complexes subject to study.

\section{Results}

In order to evaluate the appropriate computational level for the present study, a benchmark across different basis sets has been carried out. For such purpose, $1 \mathrm{SiF}: \mathrm{NH}_{3}$ complexes $\left(1 \mathrm{SiF}_{\mathrm{A}}: \mathrm{NH}_{3}\right.$, $1 \mathrm{SiF}_{\mathrm{H}}: \mathrm{NH}_{3}$, and $1 \mathrm{SiF}_{\mathrm{H}}{ }^{\mathrm{IMHB}}: \mathrm{NH}_{3}$ ) were optimized by means of Møller-Plesset (MP2) using different basis sets, i.e., aug-cc-pVDZ (avdz), aug-cc-pVTZ (avtz), aug-cc-pVQZ (avqz), and using Helgaker's method to extrapolate to the complete basis set (CBS) with two pairs of basis: aug-cc-pVDZ and aug-cc-pVTZ (CBS ${ }^{\mathrm{DT}}$ ) and aug-cc-pVTZ and aug-cc-pVQZ (CBS $\left.{ }^{\mathrm{TQ}}\right)$. Using those levels, the binding energies $(\mathrm{Eb})$, obtained as a difference of the energy of the complex minus the energies of the isolated monomers in their optimized structure, for these three complexes, were calculated and are summarized in Table 1. As observed, for the evolution of the energy values, avdz $<$ avtz $<$ avqz, it seems that there is a strong dependency of the binding energy with respect to the basis set size. When extrapolation to the complete basis set (CBS) is taken into account, it was also observed that extrapolations using two different pairs of basis set, $\mathrm{CBS}^{\mathrm{DT}}$ and $\mathrm{CBS}^{\mathrm{TQ}}$, also provide different results, with the latter, in our opinion, more accurate than the former. Taken into account the outcome of the current benchmark and the computational feasibility of the calculations, the MP2/CBS ${ }^{\mathrm{TQ}}$ computational method was chosen to evaluate the rest of the complexes, and from hence forth, named MP2/CBS for simplicity.

Table 1. Binding energies $\left(\mathrm{E}_{\mathrm{b}}\right)$, in $\mathrm{kJ} \cdot \mathrm{mol}^{-1}$, of $1 \mathrm{SiF}: \mathrm{NH}_{3}$ complexes at the MP2 computational level with different basis sets including extrapolation to the complete basis set limit (CBS) with two different basis set pairs.

\begin{tabular}{cccccc}
\hline & avdz $^{\mathbf{a}}$ & avtz $^{\mathbf{a}}$ & avqz $^{\mathbf{a}}$ & CBS $^{\text {DT } \mathbf{~}}$ & CBS $^{\text {TQ }} \mathbf{~}$ \\
\hline 1SiFA:NH3 & -29.3 & -25.4 & -23.8 & -24.5 & -21.8 \\
1SiFH:NH3 & -32.3 & -28.2 & -25.9 & -27.4 & -22.9 \\
1SiFHIMHB:NH3 & -40.5 & -36.3 & -34.4 & -35.4 & -31.7 \\
\hline
\end{tabular}

a avdz, avtz and avqz stand for aug-cc-pVDZ, aug-cc-pVTZ and aug-cc-pVQZ respectively. ${ }^{b}$ CBS stands for extrapolation to the complete basis set limit, and DT and TQ refer to the pair of basis set used to extrapolate: avdz-avtz and avtz-avqz, respectively.

\subsection{Allylfluorotetrel Derivatives: Effect of the Lewis Bases (1TF:LB)}

The effect of the Lewis bases upon complexation within 1TF:LB complexes (Figure 1) was evaluated using three different Lewis bases, i.e., $\mathrm{NH}_{3}, \mathrm{H}_{2} \mathrm{O}$ and $\mathrm{HCN}$. The intermolecular T $\cdots Y$ $(\mathrm{Y}=\mathrm{N}$ or $\mathrm{O})$ distances at the MP2/aug-cc-pVTZ computational level are gathered in Table 2. Molecular graphs and Cartesian coordinates can be found in the electronic supplementary information (Table S1). The intermolecular $\mathrm{Si} \cdots \mathrm{N}$ distances found in $1 \mathrm{SiF}: \mathrm{NH}_{3}$ range from $2.276\left(1 \mathrm{SiF}_{\mathrm{H}}{ }^{\mathrm{IMHB}}: \mathrm{NH}_{3}\right)$ to $2.518 \AA$ 
$\left(1 \mathrm{SiF}_{\mathrm{A}}: \mathrm{NH}_{3}\right)$, while in $1 \mathrm{GeF}: \mathrm{NH}_{3}$, the $\mathrm{Ge} \cdots \mathrm{Y}$ distance ranges from $2.450\left(1 \mathrm{GeF}_{\mathrm{H}}^{\mathrm{IMHB}}: \mathrm{NH}_{3}\right)$ to $2.661 \AA$ $\left(1 \mathrm{GeF}_{\mathrm{A}}: \mathrm{NH}_{3}\right)$. As observed, $1 \mathrm{TF}_{\mathrm{H}}{ }^{\mathrm{IMHB}}: \mathrm{NH}_{3}$ complexes present the shortest intermolecular $\mathrm{T} \cdots \mathrm{Y}$ distances (Table 2). Looking at the $1 \mathrm{SiF}_{\mathrm{A}}: \mathrm{NH}_{3}$ complex, the intermolecular $\mathrm{Si} \cdots \mathrm{N}$ distance is $2.518 \AA$. When the $1 \mathrm{SiF}_{\mathrm{H}}: \mathrm{NH}_{3}$ complex is taken into account, there is a shortening of $0.183 \AA$ on the Si $\cdots \mathrm{N}$ distance. This shortening can point to a decrease in the electron density on the $\mathrm{Si}$ atom due to the $\mathrm{OH}$ group and therefore an increase in the $\sigma$-hole depth, which eventually will enhance the tetrel bond. This shortening is even more visible in $1 \mathrm{SiF}_{\mathrm{H}}{ }^{\mathrm{IMHB}}: \mathrm{NH}_{3}$ complex $(0.242 \AA)$, which may indicate that the intramolecular hydrogen bond (IMHB) enhances the tetrel bond. In the case of $1 \mathrm{GeF}: \mathrm{LB}$ germanium complexes, similar but more pronounced trends in the intermolecular Ge $\cdots \mathrm{N}$ distances were found due to the IMHB and hydroxyl groups. Furthermore, the T-F distance was also analyzed to evaluate the polarity of the T-F bonds with the IMHB. T-F distance for the $1 \mathrm{SiF}_{\mathrm{A}}: \mathrm{NH}_{3}$ complex is $1.643 \AA$, while in $1 \mathrm{SiF}_{\mathrm{H}}: \mathrm{NH}_{3}$ and $1 \mathrm{SiF}_{\mathrm{H}}{ }^{\mathrm{IMHB}}: \mathrm{NH}_{3}$ complexes, they are 1.654 and $1.685 \AA$, respectively, indicating an increase in the charge transfer to the T-F $\sigma^{*} \mathrm{~T}-\mathrm{F}$ antibonding orbital, particularly in the complexes exhibiting IMBH. The same is true for $1 \mathrm{GeF}: \mathrm{NH}_{3}$ complexes $\left(1.768,1.776\right.$ and $1.815 \AA$ for $1 \mathrm{GeF}_{\mathrm{A}}: \mathrm{NH}_{3}$ complex, $1 \mathrm{GeF}_{\mathrm{H}}: \mathrm{NH}_{3}$ and $1 \mathrm{GeF}_{\mathrm{H}}^{\mathrm{IMHB}}: \mathrm{NH}_{3}$ complexes, respectively).
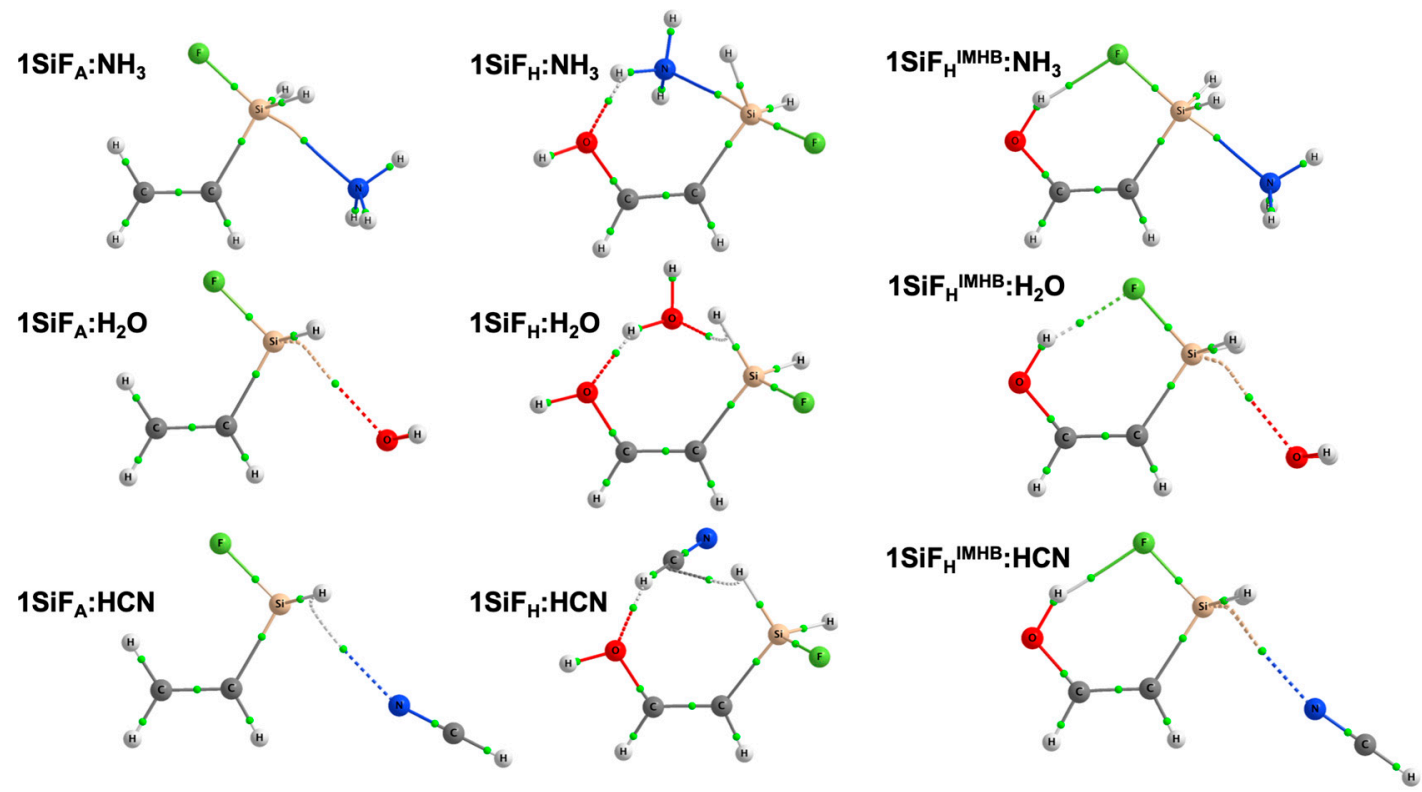

Figure 1. Molecular graphs for $1 \mathrm{SiF}: L B$ complexes at the MP2/aug-cc-pVTZ computational level. Green dots correspond to bond critical points.

Table 2. Intermolecular distances, $\mathrm{T} \cdots \mathrm{N}(\mathrm{O})(\mathrm{T}=\mathrm{Si}, \mathrm{Ge})$ in $\AA$ for 1TF:LB complexes at the MP2/aug-cc-pVTZ computational level.

\begin{tabular}{cccc}
\hline Comp. & $\mathbf{N H}_{\mathbf{3}}$ & $\mathbf{H}_{\mathbf{2}} \mathbf{O}$ & $\mathbf{H C N}$ \\
\hline $1 \mathrm{SiF}_{\mathrm{A}}: \mathrm{LB}$ & 2.518 & 2.885 & 2.991 \\
$1 \mathrm{SiF}_{\mathrm{H}}: \mathrm{LB}$ & 2.335 & 2.883 & 4.033 \\
$1 \mathrm{SiF}_{\mathrm{H}}{ }^{\mathrm{IMHB}}: \mathrm{LB}$ & 2.276 & 2.765 & 2.873 \\
$1 \mathrm{GeF}_{\mathrm{A}}: \mathrm{LB}$ & 2.661 & 2.829 & 2.898 \\
$1 \mathrm{GeF}_{\mathrm{H}}: \mathrm{LB}$ & 2.570 & 2.782 & 2.891 \\
$1 \mathrm{GeF}_{\mathrm{H}}^{\mathrm{IMHB}}: \mathrm{LB}$ & 2.450 & 2.720 & 2.789 \\
\hline
\end{tabular}

When different Lewis bases are considered (Table 2), it can be seen that complexes with ammonia have the shortest intermolecular T...Y distances. However, similar trends were observed for $1 \mathrm{TF}: \mathrm{H}_{2} \mathrm{O}$ complexes compared with 1TF: $\mathrm{NH}_{3}$ complexes, where the T...Y distance evolves as follows: $1 \mathrm{TF}_{\mathrm{A}}: \mathrm{H}_{2} \mathrm{O}$ $>1 \mathrm{TF}_{\mathrm{H}}: \mathrm{H}_{2} \mathrm{O}>1 \mathrm{TF}^{\mathrm{IMHB}} \mathrm{A}: \mathrm{H}_{2} \mathrm{O}$. In the case of $1 \mathrm{TF}: \mathrm{HCN}$ complexes, the $1 \mathrm{TF}_{\mathrm{H}}: \mathrm{HCN}$ complex seems to deviate from this trend, exhibiting a lengthening in the intermolecular $\mathrm{T} \cdots \mathrm{Y}$ distance. The reason 
behind is that in those complexes (both for $1 \mathrm{SiF}_{\mathrm{H}}: \mathrm{HCN}$ and $1 \mathrm{GeF}_{\mathrm{H}}: \mathrm{HCN}$ ), the $\mathrm{O}$ atom from the $\mathrm{OH}$ group acts as an electron donor and performs an intermolecular hydrogen bond with the Lewis base. In other words, the Lewis base acts as a hydrogen donor. That provokes a re-orientation of the Lewis base which lengthens the $\mathrm{T} \cdots \mathrm{N}$ distance. If the molecule is constrained to Cs symmetry, forcing those abovementioned to be co-planar, an imaginary frequency is found which, if followed, reverts into the actual rotated structure with $C_{1}$ symmetry.

In order to evaluate the interaction energies between 1TF compounds and the Lewis base, binding energies $\left(E_{b}\right)$, interaction energies $\left(E_{i n t}\right)$ and deformation energies $\left(E_{\text {def }}\right)$ were calculated at the MP2/CBS computational level and are summarized in Table 3 and with a histogram plotted in Figure 1. Binding energies $\left(E_{b}\right)$ and interaction energies $\left(E_{i n t}\right)$ were calculated as described in the "Materials and Methods" section. The deformation energy $\left(\mathrm{E}_{\mathrm{def}}\right)$, also called re-organization energy, was calculated as the difference between $E_{b}$ and $E_{i n t}$. $E_{b}$ ranges from -21.8 to $-41.0 \mathrm{~kJ} \cdot \mathrm{mol}^{-1}$ for 1TF: $\mathrm{NH}_{3}$ complexes. In $1 \mathrm{TF}: \mathrm{H}_{2} \mathrm{O}$, it ranges from -15.9 to $-26.9 \mathrm{~kJ} \cdot \mathrm{mol}^{-1}$, and -14.5 to $-25.1 \mathrm{~kJ} \cdot \mathrm{mol}^{-1}$ for 1TF:HCN ones. In all cases, 1TF: $\mathrm{NH}_{3}$ complexes show stronger interactions than $1 \mathrm{TF}: \mathrm{H}_{2} \mathrm{O}$ or 1TF:HCN ones as per the $\mathrm{E}_{\mathrm{b}}$ values. Focusing on the $1 \mathrm{SiF}: \mathrm{NH}_{3}$ complexes, it was observed that the $\mathrm{E}_{\mathrm{b}}$ value calculated for $1 \mathrm{SiF}_{\mathrm{A}}: \mathrm{NH}_{3}$ is $-21.8 \mathrm{~kJ} \cdot \mathrm{mol}^{-1}$, and when the hydroxyl groups are present, $\mathrm{E}_{\mathrm{b}}$ becomes slightly more negative $\left(-22.9 \mathrm{~kJ} \cdot \mathrm{mol}^{-1}\right)$, which indicates a strengthening of the interaction. This strengthening is even larger in $1 \mathrm{SiF}_{\mathrm{H}}{ }^{\mathrm{IMHB}}: \mathrm{NH}_{3}\left(\mathrm{E}_{\mathrm{b}}=-31.7 \mathrm{~kJ} \cdot \mathrm{mol}^{-1}\right)$, which shows that when the IMHB takes place, the interactions between the complex and the Lewis base are stronger. The same occurs for the $1 \mathrm{GeF}: \mathrm{NH}_{3}$ complexes. In the case of water complexes, the $\mathrm{E}_{\mathrm{b}}$ follows the same trend as in ammonia complexes. However, the $1 \mathrm{TF}_{\mathrm{H}}: \mathrm{H}_{2} \mathrm{O}$ complex presents slightly more negative values of $\mathrm{E}_{\mathrm{b}}$ than the $1 \mathrm{TF}_{\mathrm{H}}{ }^{\mathrm{IMHB}}: \mathrm{H}_{2} \mathrm{O}$ complex, which is likely due to a secondary intermolecular hydrogen bond in which water is acting as a hydrogen bond donor (Figure 1). This could be the reason behind the extra stabilization in the $\mathrm{E}_{\mathrm{b}}$. The opposite happens for the 1TF:HCN complexes in which $1 \mathrm{TF}_{\mathrm{H}}: \mathrm{HCN}$ is less stable than its parental complex, $1 \mathrm{TF}_{\mathrm{A}}: \mathrm{HCN}$. As explained above, this is provoked by a re-orientation of the Lewis base in the $1 \mathrm{TF}_{\mathrm{H}}: \mathrm{HCN}$ due to the presence of the hydroxyl group, which acts as an electron donor and forms an intermolecular hydrogen bond with the HCN (Figure 1). Poor correlations between the binding energy and the intermolecular distances were found, which may be due to the secondary hydrogen bonds in the $1 \mathrm{TF}_{\mathrm{H}}: \mathrm{LB}$ complexes and electronic repulsions between atoms due to the electron lone pairs [42].

Table 3. Binding energies $\left(E_{b}\right)$, interaction energies $\left(E_{\text {int }}\right)$ and deformation energies $\left(E_{\text {def }}\right)$ for the 1TF:LB complexes at the MP2/CBS computational level, in $\mathrm{kJ} \cdot \mathrm{mol}^{-1}$.

\begin{tabular}{cccccccccc}
\hline \multirow{2}{*}{ Complex } & \multicolumn{3}{c}{$\mathbf{E}_{\mathbf{b}}$} & \multicolumn{3}{c}{$\mathbf{E}_{\text {int }}$} & \multicolumn{3}{c}{$\mathbf{E}_{\text {def }}$} \\
\cline { 2 - 9 } & $\mathbf{N H}_{\mathbf{3}}$ & $\mathbf{H}_{\mathbf{2}} \mathbf{O}$ & $\mathbf{H C N}$ & $\mathbf{N H}_{\mathbf{3}}$ & $\mathbf{H}_{\mathbf{2}} \mathbf{O}$ & $\mathbf{H C N}$ & $\mathbf{N H}_{\mathbf{3}}$ & $\mathbf{H}_{\mathbf{2}} \mathbf{O}$ & $\mathbf{H C N}$ \\
\hline $1 \mathrm{SiF}_{\mathrm{A}}: \mathrm{NH}_{3}$ & -21.8 & -15.9 & -14.6 & -35.2 & -17.7 & -16.1 & 13.6 & 1.8 & 1.4 \\
$1 \mathrm{SiF}_{\mathrm{H}}: \mathrm{NH}_{3}$ & -22.9 & -19.2 & -14.5 & -51.3 & -24.1 & -16.7 & 28.4 & 4.9 & 2.2 \\
$1 \mathrm{SiF}_{\mathrm{H}}{ }^{\mathrm{IMHB}}: \mathrm{NH}_{3}$ & -31.7 & -18.2 & -16.9 & -60.6 & -21.2 & -19.2 & 28.8 & 3.0 & 2.4 \\
$1 \mathrm{GeF}_{\mathrm{A}}: \mathrm{NH}_{3}$ & -31.2 & -21.6 & -21.6 & -38.0 & -23.1 & -22.9 & 6.8 & 1.5 & 1.3 \\
$1 \mathrm{GeF}_{\mathrm{H}}: \mathrm{NH}_{3}$ & -31.9 & -26.9 & -14.7 & -43.9 & -31.1 & -16.6 & 12.0 & 4.2 & 1.9 \\
$1 \mathrm{GeF}_{\mathrm{H}}{ }^{\mathrm{IMHB}}: \mathrm{NH}_{3}$ & -41.0 & -25.1 & -25.6 & -56.1 & -27.6 & -27.9 & 15.1 & 2.4 & 2.3 \\
\hline
\end{tabular}

To evaluate the re-organization energy, i.e., the relaxation energy of the monomers and the energy penalty upon complexation, the interaction energies were evaluated. As observed (Figure 2), $E_{\text {int }}$ values for all the complexes studied are more negative than the corresponding $E_{b}$ values; this is particularly dramatic for the 1SiF: $\mathrm{NH}_{3}$ complexes in which the $\mathrm{E}_{\text {int }}$ values are the most negative of all complexes. When the difference of both quantities $\left(E_{b}-E_{i n t}\right)$ is taken into account, the deformation energy, $E_{\text {def }}$, values (Table 3 ) indicate that $1 \mathrm{TF}: \mathrm{NH}_{3}$ complexes suffer a larger penalty in binding energy due to re-organization than 1TF: $\mathrm{H}_{2} \mathrm{O}$ and 1TF:HCN complexes. 


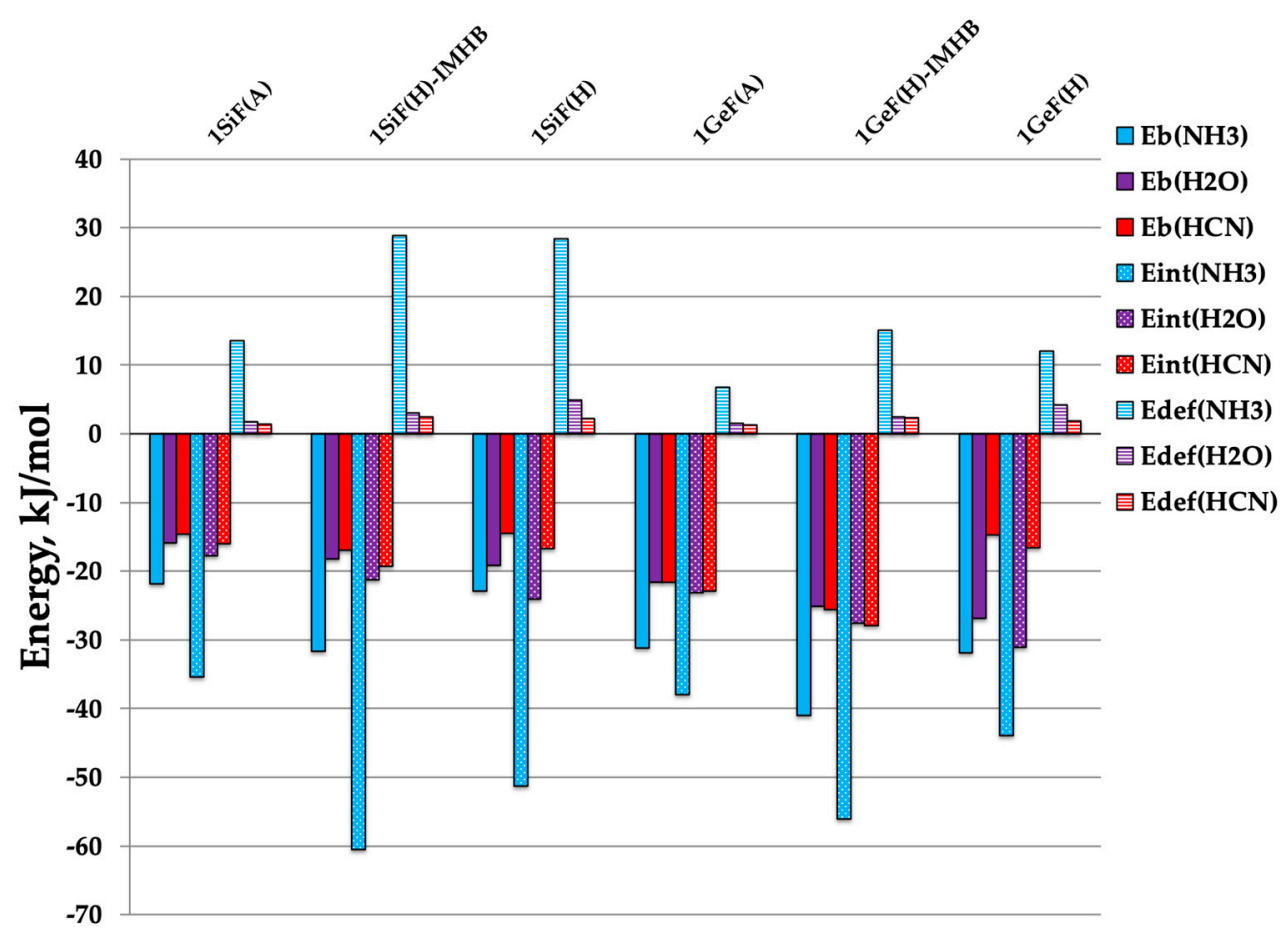

Figure 2. Histogram for the different energies: $E_{b}$ (solid), $E_{i n t}$ (dotted) and $E_{\text {def }}$ (stripped) for each Lewis base considered: $\mathrm{NH}_{3}$ (blue), $\mathrm{H}_{2} \mathrm{O}$ (purple) and $\mathrm{HCN}$ (red).

\subsection{Allylhalotetrel Derivatives: Effect of the Halogen (1TX: $\mathrm{NH}_{3}$ )}

Once the effect of the Lewis base on the tetrel interaction and the relative energy between the three different complexes was determined, the effect of substituting the halogen atom $(\mathrm{X})$ bonded to the tetrel atom ( $\mathrm{T}=\mathrm{Si}$ or $\mathrm{Ge}$ ) was studied. For this purpose, and keeping the same Lewis base $\left(\mathrm{NH}_{3}\right)$, fluorine atom was replaced by a chlorine atom within the 1TX:NH3 complexes. Intermolecular T $\cdots \mathrm{N}$ distances are summarized in Table 4 . The shortest $\mathrm{T} \cdots \mathrm{N}$ distance corresponds to the $1 \mathrm{SiF}_{\mathrm{H}}{ }^{\mathrm{IMHB}}: \mathrm{NH}_{3}$ complex $\left(2.276 \AA\right.$ ) while the largest is found in the $1 \mathrm{GeCl}_{\mathrm{A}}: \mathrm{NH}_{3}$ complex $(2.767 \AA)$. As observed in Table 4, 1TF: $\mathrm{NH}_{3}$ complexes exhibit shorter intermolecular T $\cdots$ Y distances than $1 \mathrm{TCl}: \mathrm{NH}_{3}$ ones, with the exception of the $1 \mathrm{SiF}_{\mathrm{H}}: \mathrm{NH}_{3}$ complex, which presents a slightly longer $(0.044 \AA) \mathrm{T} \cdots \mathrm{N}$ distance than the $1 \mathrm{SiCl}_{\mathrm{H}}: \mathrm{NH}_{3}$ complex. Furthermore, the T-F distances found for 1TF: $\mathrm{NH}_{3}$ complexes suggest an increase in the polarity of the T-F bond, and a similar phenomenon is observed for 1TCl: $\mathrm{NH}_{3}$ (Table 4) in which the T-Cl bond distances exhibit a lengthening in $1 \mathrm{TX}_{\mathrm{H}}: \mathrm{NH}_{3}$ and $1 \mathrm{TX}_{\mathrm{H}}{ }^{\mathrm{IMHB}}: \mathrm{NH}_{3}$ complexes with respect to those in $1 \mathrm{TX}_{\mathrm{A}}: \mathrm{NH}_{3}$ complexes.

Table 4. Binding energies $\left(E_{b}\right)$, interaction energies $\left(E_{\text {int }}\right)$ and deformation energies $\left(E_{\text {def }}\right)$, at the MP2/CBS computational level, in $\mathrm{kJ} \cdot \mathrm{mol}^{-1}$, intermolecular $\mathrm{T} \cdots \mathrm{N}$ distances and $\mathrm{T}-\mathrm{X}$ bond distances ( $\mathrm{T}=\mathrm{Si}, \mathrm{Ge}$ and $\mathrm{X}=\mathrm{F}, \mathrm{Cl}$ ), in $\AA$ for 1TX:NH 3 complexes at the MP2/aug-cc-pVTZ computational level.

\begin{tabular}{|c|c|c|c|c|c|c|c|c|c|c|}
\hline \multirow[b]{2}{*}{ Complex } & \multicolumn{2}{|c|}{$E_{b}$} & \multicolumn{2}{|c|}{$E_{\text {int }}$} & \multicolumn{2}{|c|}{$E_{\text {def }}$} & \multicolumn{2}{|c|}{$\mathbf{T} \cdots \mathrm{N}$} & \multicolumn{2}{|c|}{ T-X } \\
\hline & $X=F$ & $\mathrm{X}=\mathrm{Cl}$ & $X=F$ & $\mathrm{X}=\mathrm{Cl}$ & $\mathrm{X}=\mathrm{F}$ & $\mathrm{X}=\mathrm{Cl}$ & $X=F$ & $\mathrm{X}=\mathrm{Cl}$ & $X=F$ & $\mathrm{X}=\mathrm{Cl}$ \\
\hline $1 \mathrm{SiX}_{\mathrm{A}}: \mathrm{NH}_{3}$ & -21.8 & -20.1 & -35.4 & -30.5 & 13.6 & 10.4 & 2.518 & 2.640 & 1.643 & 2.110 \\
\hline 1SiX $_{\mathrm{H}}: \mathrm{NH}_{3}$ & -22.9 & -24.5 & -51.3 & -58.5 & 28.4 & 34.1 & 2.335 & 2.291 & 1.654 & 2.156 \\
\hline $1 \mathrm{SiX}_{\mathrm{H}}{ }^{\mathrm{IMHB}}: \mathrm{NH}_{3}$ & -31.7 & -27.5 & -60.6 & -58.9 & 28.8 & 31.4 & 2.276 & 2.291 & 1.685 & 2.185 \\
\hline $1 \mathrm{GeX}_{\mathrm{A}}: \mathrm{NH}_{3}$ & -31.2 & -28.2 & -38.0 & -32.7 & 6.8 & 4.6 & 2.661 & 2.767 & 1.768 & 2.193 \\
\hline $1 \mathrm{GeX}_{\mathrm{H}}: \mathrm{NH}_{3}$ & -31.9 & -31.6 & -43.9 & -42.3 & 12.0 & 10.7 & 2.570 & 2.603 & 1.776 & 2.217 \\
\hline $1 \mathrm{GeX}_{\mathrm{H}}{ }^{\mathrm{IMHB}}: \mathrm{NH}_{3}$ & -41.0 & -34.8 & -56.1 & -46.6 & 15.1 & 11.8 & 2.450 & 2.545 & 1.815 & 2.251 \\
\hline
\end{tabular}

In terms of binding energies, 1TF: $\mathrm{NH}_{3}$ complexes show slightly more negative $\mathrm{E}_{\mathrm{b}}$ values than 1TCl: $\mathrm{NH}_{3}$ complexes, which may be caused by an increase in the depth of the $\sigma$-hole on the tetrel atom 
(Table S2). Fluorine atoms withdraw more electron density, therefore the $\sigma$-hole on the tetrel atom is deeper, so 1TF: $\mathrm{NH}_{3}$ complexes will have more negative $\mathrm{E}_{\mathrm{b}}$ values than 1TCl: $\mathrm{NH}_{3}$ complexes. Once again, the only exception corresponds to $1 \mathrm{SiCl}_{\mathrm{H}}: \mathrm{NH}_{3}$ with an $\mathrm{E}_{\mathrm{b}}$ value of $-24.5 \mathrm{~kJ} \cdot \mathrm{mol}^{-1}$, while the $1 \mathrm{SiF}_{\mathrm{H}}: \mathrm{NH}_{3}$ $\mathrm{E}_{\mathrm{b}}$ value is $-22.9 \mathrm{~kJ} \cdot \mathrm{mol}^{-1}$. In both cases, the halogen atom does not form any IMHBs, which reinforces the idea that IMHBs are stabilizing the complex. Regarding the interaction energy, $\mathrm{E}_{\text {int }}$ is shown to be more negative than $\mathrm{E}_{\mathrm{b}}$, which is as expected because the $\mathrm{E}_{\mathrm{b}}$ suffers from the re-organization penalty. In fact, $E_{\text {def }}$ values indicate that this penalty is larger for silyl complexes than germanium ones, and within the same tetrel family (1TX: $\mathrm{NH}_{3}$ ), the deformation energy is much larger, up to three times larger in some cases, for complexes with hydroxyl groups $\left(1 \mathrm{TF}_{\mathrm{H}}: \mathrm{NH}_{3}\right.$ and $\left.1 \mathrm{TX}{ }_{\mathrm{H}}{ }^{\mathrm{IMHB}}: \mathrm{NH}_{3}\right)$ than in their parental complexes $\left(1 \mathrm{SiX}{ }_{\mathrm{A}}: \mathrm{NH}_{3}\right)$.

\subsection{Phenyl Halogen Tetrel Derivatives: Effect of the Backbone (2TX: $\left.\mathrm{NH}_{3}\right)$}

Finally, different carbon backbones have been evaluated by means of replacing the allyl backbone with a phenyl ring focusing only on complexes with ammonia. The intermolecular $T \cdots N$ distances, $E_{b}$, $\mathrm{E}_{\mathrm{int}}, \mathrm{E}_{\mathrm{def}}$ and T-X bond distances are summarized in Table 5. Intermolecular T $\cdots \mathrm{N}$ distances in $2 \mathrm{TX}: \mathrm{NH}_{3}$ complexes present similar values to those in 1TX: $\mathrm{NH}_{3}$ complexes, but with slight variations. $2 \mathrm{TF}_{\mathrm{A}}: \mathrm{NH}_{3}$ complexes (both for Si and Ge) exhibit longer T $\cdots \mathrm{N}$ distances (2.596 and $2.703 \AA$, respectively) than $1 \mathrm{TF}_{\mathrm{A}}: \mathrm{NH}_{3}$ complexes (2.518 and 2.661 $\AA$ ), and the same occurs for $2 \mathrm{TX}_{\mathrm{H}}{ }^{\mathrm{IMHB}}: \mathrm{NH}_{3}$ complexes, while the opposite is true for $2 \mathrm{TF}_{\mathrm{H}}: \mathrm{NH}_{3}\left(\mathrm{Si}=2.330\right.$ and $\mathrm{Ge}=2.553 \AA$ ) compared with $1 \mathrm{TF}_{\mathrm{H}}: \mathrm{NH}_{3}(\mathrm{Si}=2.335$ and $\mathrm{Ge}=2.570 \AA$ ). As in 1TX: $\mathrm{NH}_{3}$ complexes, the ones with hydroxyl groups present, both $2 \mathrm{TX}_{\mathrm{H}}: \mathrm{NH}_{3}$ and $2 \mathrm{TX}_{\mathrm{H}}{ }^{\mathrm{IMHB}}: \mathrm{NH}_{3}$ exhibit a shortening of the $\mathrm{T} \cdots \mathrm{N}$ distances. However, looking at the $\mathrm{T}-\mathrm{X}$ bond distances, both for $\mathrm{X}=\mathrm{F}$ and $\mathrm{Cl}$, a lengthening is observed in $2 \mathrm{TX}_{\mathrm{H}}: \mathrm{NH}_{3}$ and $2 \mathrm{TX}_{\mathrm{H}}^{\mathrm{IMHB}}: \mathrm{NH}_{3}$ consistent with the results mentioned above and the increase in polarity of the $\mathrm{T}-\mathrm{X}$ bond with the presence of hydroxyl groups and IMHBs.

Table 5. Binding energies $\left(E_{b}\right)$, interaction energies $\left(E_{\text {int }}\right)$ and deformation energies $\left(E_{\text {def }}\right)$, at the MP2/CBS computational level, in $\mathrm{kJ} \cdot \mathrm{mol}^{-1}$, intermolecular $\mathrm{T} \cdots \mathrm{N}$ distances and $\mathrm{T}-\mathrm{X}$ bond distances ( $\mathrm{T}=\mathrm{Si}, \mathrm{Ge}$ and $\mathrm{X}=\mathrm{F}, \mathrm{Cl}$ ), in $\AA$ for 2TX:NH 3 complexes at the MP2/aug-cc-pVTZ computational level.

\begin{tabular}{|c|c|c|c|c|c|c|c|c|c|c|}
\hline \multirow[b]{2}{*}{ Complex } & \multicolumn{2}{|c|}{$E_{b}$} & \multicolumn{2}{|c|}{$E_{\text {int }}$} & \multicolumn{2}{|c|}{$E_{\text {def }}$} & \multicolumn{2}{|c|}{$\mathbf{T} \cdots \mathrm{N}$} & \multicolumn{2}{|c|}{ T-X } \\
\hline & $X=F$ & $\mathrm{X}=\mathrm{Cl}$ & $X=F$ & $\mathrm{X}=\mathrm{Cl}$ & $X=F$ & $\mathrm{X}=\mathrm{Cl}$ & $X=F$ & $\mathrm{X}=\mathrm{Cl}$ & $X=F$ & $\mathrm{X}=\mathrm{Cl}$ \\
\hline $2 \mathrm{SiX}_{\mathrm{A}}: \mathrm{NH}_{3}$ & -21.5 & -21.5 & -30.99 & -30.78 & 9.5 & 9.2 & 2.596 & 2.635 & 1.638 & 2.111 \\
\hline $2 \mathrm{SiX}_{\mathrm{H}}: \mathrm{NH}_{3}$ & -23.7 & -28.7 & -59.13 & -61.07 & 33.9 & 33.2 & 2.330 & 2.305 & 1.652 & 2.150 \\
\hline $2 \mathrm{SiX}_{\mathrm{H}}{ }^{\mathrm{IMHB}}: \mathrm{NH}_{3}$ & -25.2 & -27.9 & -55.27 & -59.79 & 31.6 & 31.1 & 2.301 & 2.291 & 1.677 & 2.176 \\
\hline $2 \mathrm{GeX}_{\mathrm{A}}: \mathrm{NH}_{3}$ & -29.0 & -27.8 & -34.45 & -31.73 & 5.4 & 3.9 & 2.703 & 2.771 & 1.766 & 2.194 \\
\hline $2 \mathrm{GeX}_{\mathrm{H}}: \mathrm{NH}_{3}$ & -32.1 & -31.3 & -55.44 & -48.18 & 15.3 & 13.3 & 2.553 & 2.594 & 1.776 & 2.214 \\
\hline $2 \mathrm{GeX}_{\mathrm{H}}{ }^{\mathrm{IMHB}}: \mathrm{NH}_{3}$ & -40.1 & -34.9 & -47.60 & -44.99 & 15.5 & 13.7 & 2.485 & 2.554 & 1.809 & 2.244 \\
\hline
\end{tabular}

Binding energies for 2TX: $\mathrm{NH}_{3}$ complexes are found to be within the same range as 1TX:NH complexes, with $2 \mathrm{TX}_{\mathrm{A}}: \mathrm{NH}_{3}$ and $2 \mathrm{TX}_{\mathrm{H}}{ }^{\mathrm{IMHB}}: \mathrm{NH}_{3}$ complexes exhibiting larger $\mathrm{E}_{\mathrm{b}}$ values than their corresponding allyl counterparts, while $2 \mathrm{TX}_{\mathrm{H}}: \mathrm{NH}_{3}$ complexes present slightly smaller $\mathrm{E}_{\mathrm{b}}$ values than $1 \mathrm{TX}_{\mathrm{H}}: \mathrm{NH}_{3}$ complexes, both for $\mathrm{T}=\mathrm{Si}, \mathrm{Ge}$ and $\mathrm{X}=\mathrm{F}, \mathrm{Cl}$. Eb values show that in all cases, $2 \mathrm{SiCl}: \mathrm{NH}_{3}$ complexes have a stronger interaction with $\mathrm{NH}_{3}$ than $2 \mathrm{SiF}: \mathrm{NH}_{3}$ complexes, while the opposite is true for the germanium derivatives. In terms of interaction energies, $\mathrm{E}_{\text {int, }}$, values in Table 5 reveal similar features to those found for the allyl complexes, i.e., large negative values of $E_{\text {int, }}$ twice as much in some cases (for example: $2 \mathrm{SiX} \mathrm{H}_{\mathrm{H}}: \mathrm{NH}_{3}$ ). This indicates a substantial re-organization energy, which was also confirmed when the $E_{\text {def }}$ values were analyzed. $E_{\text {def }}$ values are very large, in fact, silyl complexes with hydroxyl groups $\left(2 \mathrm{SX} \mathrm{H}_{\mathrm{H}}: \mathrm{NH}_{3}\right)$ present the largest deformation energies, as occurred in $1 \mathrm{SX}_{\mathrm{H}}: \mathrm{NH}_{3}$ complexes. This can be explained in terms of electronic repulsion between groups, as explained above [42].

If we compare the evolution of the binding energy across the 2TX: $\mathrm{NH}_{3}$ complexes, it is seen that the presence of hydroxyl $\left(2 \mathrm{TX}_{\mathrm{H}}: \mathrm{NH}_{3}\right)$ enhances the interaction with the Lewis base in about $10.2 \%$ 
$\left(2 \mathrm{SiF}_{\mathrm{H}}: \mathrm{NH}_{3}\right)$ and $10.7 \%\left(2 \mathrm{GeF}_{\mathrm{H}}: \mathrm{NH}_{3}\right)$. This enhancement is even larger within $2 \mathrm{TCl}: \mathrm{NH}_{3}$ complexes (33.4\% and $12.4 \%$ in $2 \mathrm{SiCl}_{\mathrm{H}}: \mathrm{NH}_{3}$ and $2 \mathrm{GeCl}_{\mathrm{H}}: \mathrm{NH}_{3}$, respectively). Besides, the enhancement of the binding energy reaches the maximum value when the IMHB takes place in the complex, reaching up to $38.2 \%$ of enhancement on the $\mathrm{E}_{\mathrm{b}}$ with respect to the $2 \mathrm{TX}_{\mathrm{A}}: \mathrm{NH}_{3}$ complex.

\subsection{Electron Density Properties}

The electron density properties of the intermolecular tetrel interactions were studied by means of atoms in molecules (AIM) theory. In most of the cases, the tetrel bond is characterized by the existence of a bond critical point (BCP) between the tetrel atom and the electron donor on the Lewis base moiety ( $\mathrm{N}$ or $\mathrm{O}$ ) (Table $\mathrm{S1}$ ). As it is denoted in the literature, this should be taken carefully, since the opposite is not true, i.e., the absence of a BCP between two interacting atoms does not necessary imply the absence of interactions [43]. It has been found that in some cases dominant weak interactions exhibit neither BCP nor bond paths [44]. However, while the BCPs should be taken cautiously and there is a huge debate about the interpretation of the bond paths and their relationship to the chemical bond, the existence of BCPs and their associated properties has been proven to be a useful tool to identify non-covalent interactions across the different varieties: hydrogen [45,46], halogen [47], pnicogen [48], chalcogen [14] and tetrel bonds [49].

The electron density parameters obtained are summarized in Table S3. Values of the electron density at the bond critical ( $\rho_{\mathrm{BCP}}$ ) for $1 \mathrm{SiF}: \mathrm{NH}_{3}$ and $1 \mathrm{GeF}: \mathrm{NH}_{3}$ complexes range from 0.0270 to 0.045 a.u. and 0.0241 to 0.0366 a.u., respectively. Values for $1 \mathrm{SiF}: \mathrm{HCN}$ and $1 \mathrm{GeF}: \mathrm{HCN}$ complexes, which show similar $\mathrm{T} \cdots \mathrm{N}$ interactions, are smaller at $0.0101-0.0129$ a.u. and $0.0132-0.0158$ a.u., respectively. This is aligned with the interaction and binding energy values found and the intermolecular $\mathrm{T} \cdots \mathrm{N}$ distance evolution. Similar comparison trends are found for the Laplacian $\left(\nabla^{2} \rho_{\mathrm{BCP}}\right)$ values and total electron energy density $\left(\mathrm{H}_{\mathrm{BCP}}\right)$ values between those complexes.

1TCl: $\mathrm{NH}_{3}$ complexes show very similar $\rho_{\mathrm{BCP}}$ values to $1 \mathrm{TF}: \mathrm{NH}_{3}$, concomitantly with similar Laplacian and $\mathrm{H}_{\mathrm{BCP}}$ values, with slight differences. Cremer et al. demonstrated that the sign of the total electron energy density $\left(\mathrm{H}_{\mathrm{BCP}}\right)$, defined as the sum of $\mathrm{G}_{\mathrm{BCP}}+\mathrm{V}_{\mathrm{BCP}}$, could be used to indicate the degree of covalency for chemical interactions [50-52]. $\mathrm{H}_{\mathrm{BCP}}$ values have been found to be negative for interactions that significantly share electrons. In fact, in other interactions, such as pnicogen bonds, the electron density increment within intermonomeric regions has been postulated as a stabilizing factor [53]. As observed for 1TX: $\mathrm{NH}_{3}$ complexes (Table S3), negative $\mathrm{H}_{\mathrm{BCP}}$ values are found and they may indicate a certain covalent character of the tetrel interaction. Furthermore, $1 \mathrm{TX}_{\mathrm{H}}{ }^{\mathrm{IMHB}}: \mathrm{NH}_{3}$ complexes present the most negative $\mathrm{H}_{\mathrm{BCP}}$ values, which reinforces the idea that hydroxyl groups performing IMHB enhance tetrel bonds.

Exponential relationships have been found between the electron density at the BCP and the

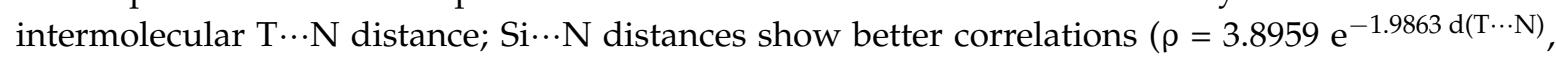

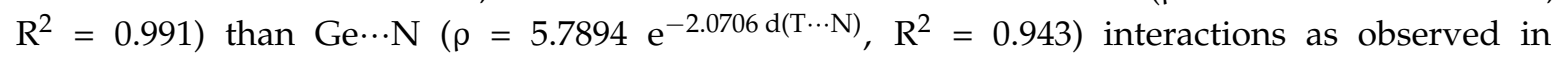
Figure 3a. Similar relationships have also been found between the Laplacian and $\mathrm{T} \cdots \mathrm{N}$ distance $\left(\nabla^{2} \rho=0.76454 \mathrm{e}^{-1.0514 \mathrm{~d}(\mathrm{~T} \cdots \mathrm{N})}, \mathrm{R}^{2}=0.947\right.$ and $\nabla^{2} \rho=3.6611 \mathrm{e}^{-1.5177 \mathrm{~d}(\mathrm{~T} \cdots \mathrm{N})}, \mathrm{R}^{2}=0.982$ for $\mathrm{T}=\mathrm{Si}$ and Ge complexes, respectively) as depicted in Figure $3 \mathrm{~b}$.

In order to provide further insight into the electron density changes upon complexation, electron density shift maps (EDS) at the \pm 0.002 a.u. isosurfaces are plotted in Figure 4 . Blue areas correspond to those regions with a decrease in the electron density upon complexation, while yellow areas indicate those regions in which an increase in the electron density occurs. As observed, the $1 \mathrm{SiF}_{\mathrm{A}}: \mathrm{NH}_{3}$ complex shows an increase (positive yellow area) in electron density between the $\mathrm{N}$ and $\mathrm{Si}$ atoms, corresponding to the donation of electron density from the Lewis base into the Si $\sigma$-hole. This pattern of depletion-increase in electron density has been observed for a wide range of inter/intramolecular interactions [14,54-58]. When $1 \mathrm{SiF}_{\mathrm{H}}: \mathrm{NH}_{3}$ and $1 \mathrm{SiF}_{\mathrm{H}}{ }^{\mathrm{IMHB}}: \mathrm{NH}_{3}$ complexes are considered, the changes in electron density upon complexation become even more evident: blue (negative) and yellow (positive) areas are larger for $1 \mathrm{SiF}_{\mathrm{H}}: \mathrm{NH}_{3}$ and $1 \mathrm{SiF}_{\mathrm{H}}{ }^{\mathrm{IMHB}}: \mathrm{NH}_{3}$ complexes than for $1 \mathrm{SiF}_{\mathrm{A}}: \mathrm{NH}_{3}$ complexes, 
particularly in the areas surrounding the ammonia in which a drastic decrease in electron density is observed. This decrease is due to the larger electron density donation from the Lewis base in complexes with hydroxyl groups $\left(1 \mathrm{SiF}_{\mathrm{H}}: \mathrm{NH}_{3}\right.$ and $\left.1 \mathrm{SiF}_{\mathrm{H}}{ }^{\mathrm{IMHB}}: \mathrm{NH}_{3}\right)$ than in the $1 \mathrm{SiF}_{\mathrm{A}}: \mathrm{NH}_{3}$ one. When the phenyl backboned complexes are taken into account, the electron density shift maps show very similar increase/decrease patterns compared to the allyl one. Furthermore, there are no appreciable changes in the shape or size of the blue and yellow areas in comparison with the $1 \mathrm{SiF}: \mathrm{NH}_{3}$ complexes, which is in consonance with the binding/interaction energies and the evolution of intermolecular $\mathrm{T} \cdots \mathrm{N}$ distances.

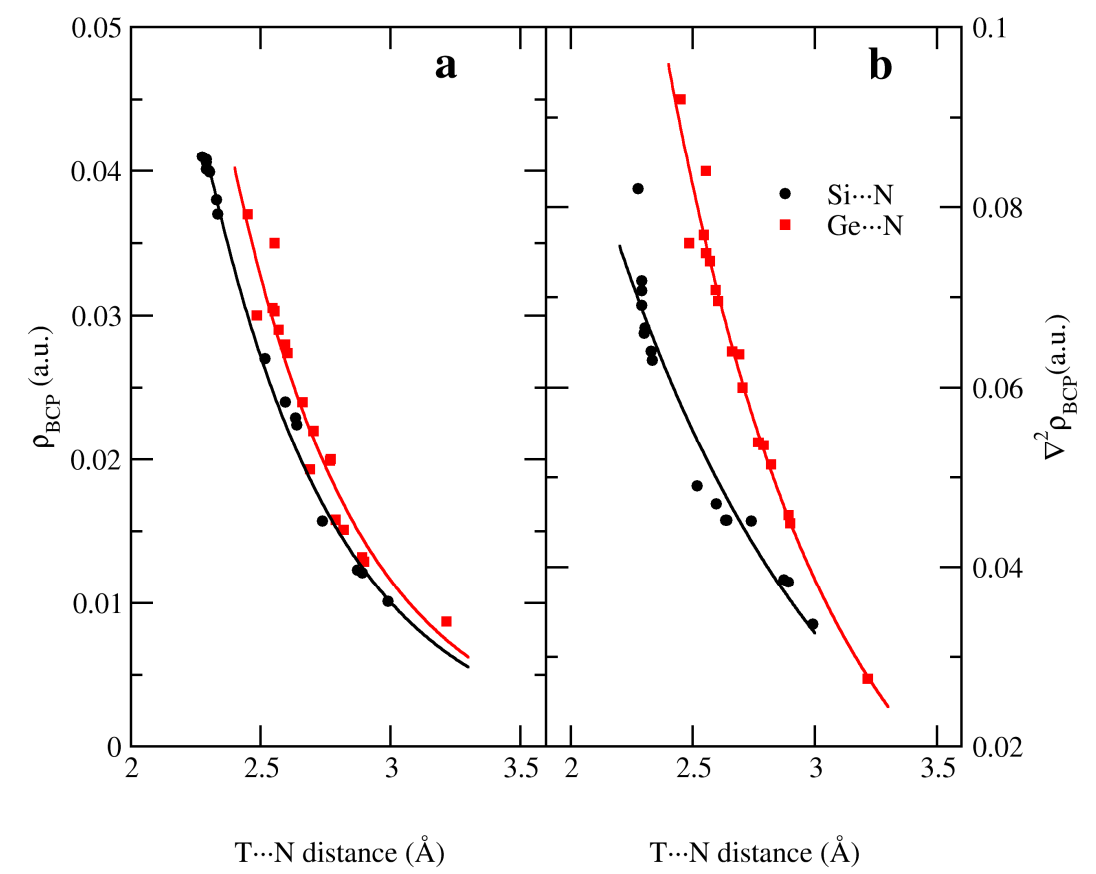

Figure 3. Exponential relationships between (a) electron density at the bond critical point and (b) Laplacian at the bond critical point with the intermolecular T $\cdots \mathrm{N}$ distance at the MP2/aug-cc-pVTZ computational level.

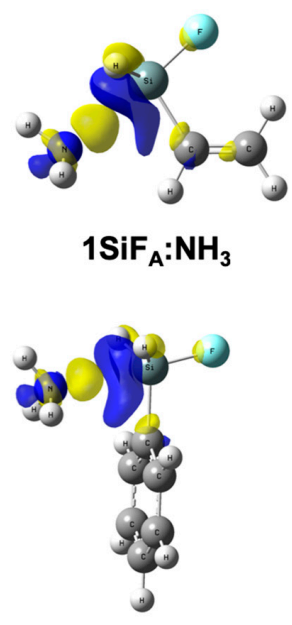

$2 \mathrm{SiF}_{\mathrm{A}}: \mathrm{NH}_{3}$

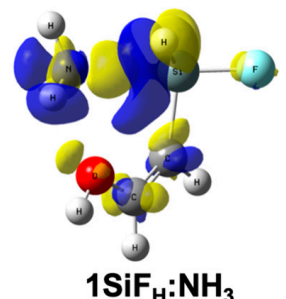

$1 \mathrm{SiF}_{\mathrm{H}}: \mathrm{NH}_{3}$

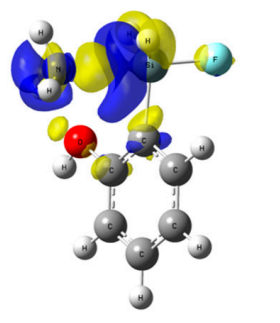

$2 \mathrm{SiF}_{\mathrm{H}}: \mathrm{NH}_{3}$

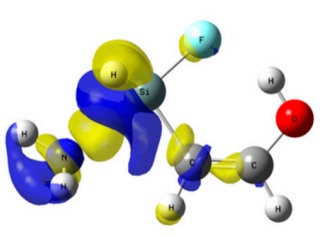

$1 \mathrm{SiF}_{\mathrm{H}}{ }^{\mathrm{IMBH}}: \mathrm{NH}_{3}$

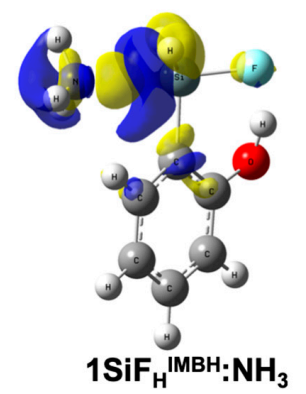

Figure 4. Electron density shift maps for the $\mathrm{nSiF}: \mathrm{NH}_{3}(\mathrm{n}=1,2)$ complexes on the \pm 0.002 a.u. electron density isosurfaces at the MP2/aug-cc-pVTZ computational level. Blue and yellow areas correspond to regions with a decrease and increase in electron density, respectively. 


\section{Materials and Methods}

The structures of the complexes were optimized at the Møller-Plesset (MP2) [59]/aug-cc-pVTZ [60,61] computational level. Harmonic vibrational frequencies were computed at the same level used for the geometry optimizations in order to confirm that the stationary points are local minima. Calculations were performed using the Gaussian09 program [62]. Binding energies $\left(E_{b}\right)$ were calculated as a difference in the energy of the complex minus the energy of each monomer in their optimized geometry. Interaction energies $\left(E_{i n t}\right)$ were calculated as a difference in the energy of the complex minus the energy of each monomer, keeping the monomer geometry fixed in the complex optimized geometry. Finally, the deformation energy $\left(E_{\mathrm{def}}\right)$, also called the re-organization energy, was calculated as the difference between $E_{\mathrm{b}}$ and $E_{\text {int }}$. In order to provide more accurate energies the interaction energies were also estimated at the MP2/CBS (complete basis set) limit using the method of Helgaker et al. [63,64] from the calculated interaction energies with the aug-cc-pVTZ and aug-cc-pVQZ basis sets:

$$
\begin{aligned}
& E_{X}^{H F}=E_{C B S}^{H F}+A e^{-\propto X} \\
& E_{X}^{M P 2}=E_{C B S}^{M P 2}+B X^{-3}
\end{aligned}
$$

where $E_{X}$ and $E_{\mathrm{CBS}}$ are the energies for the basis set with the largest angular momentum $X$ and for the complete basis set, respectively.

The atoms in molecules (AIM) methodology [65,66] was used to analyze the electron density of the systems with the AIMAll program [67].

The intermolecular electron density shift (EDS) [58] was calculated using Equation (3):

$$
\mathrm{EDS}=\rho\left(\mathrm{nTX}: \mathrm{NH}_{3}\right)-\rho(\mathrm{nTX})-\rho\left(\mathrm{NH}_{3}\right)
$$

where $\rho\left(\mathrm{nTX}: \mathrm{NH}_{3}\right), \rho(\mathrm{nTX})$ and $\rho\left(\mathrm{NH}_{3}\right)$ stand for the electron density of the complex and both fragments in the geometry of the complex, respectively.

\section{Conclusions}

The complexation of a series of silyl (nSiX:LB) and germanium (nGeX:LB) complexes, with two different halogen atoms $(\mathrm{X}=\mathrm{F}$ and $\mathrm{Cl})$ was studied. Three different Lewis bases $\left(\mathrm{NH}_{3}, \mathrm{H}_{2} \mathrm{O}\right.$ and $\left.\mathrm{HCN}\right)$ were considered to form the complexes and the effect of the existence or absence of intramolecular hydrogen bonds on the intermolecular tetrel bond were analyzed.

Calculated geometrical parameters and binding and interaction energies suggested that the presence of hydroxyl groups enhances the intermolecular tetrel bond. In general, $n T X_{H}: \mathrm{LB}_{\text {and }}$ $\mathrm{nTX}_{\mathrm{H}}{ }^{\mathrm{IMHB}}: \mathrm{LB}$ complexes presented shorter intermolecular T‥Y distances than their parental nTX ${ }_{\mathrm{A}}: \mathrm{LB}$ complexes. This fact, concomitantly with the $E_{b}$ values found: $E_{b}\left(n_{T X}{ }^{I M H B}: L B\right)<E_{b}\left(n T X_{A}: L B\right)$, indicates a strengthening of the tetrel bond with the presence of hydroxyl groups, whether it is forming an IMHB or not. However, the data analyzed reveal that when the IMHB takes place, the enhancement is even larger than without it.

Regarding the Lewis base, complexes with $\mathrm{NH}_{3}$ showed the most negative binding energies, followed by $\mathrm{H}_{2} \mathrm{O}$ and $\mathrm{HCN}$.

The substitution of the fluorine atom $(\mathrm{X}=\mathrm{F})$ by a chlorine atom, in general, weakens the tetrel bond in allyl complexes (1TCl: $\left.\mathrm{NH}_{3}\right)$, which show $\mathrm{E}_{\mathrm{b}}$ and $\mathrm{E}_{\mathrm{int}}$ values larger than its fluorine counterparts.

Finally, the effect of the carbon backbone was evaluated using two different backbones, allyl and phenyl. In spite of some differences, the intermolecular $\mathrm{T} \cdots \mathrm{N}$ distances and binding energies remain within the same range values.

Supplementary Materials: The supplementary materials are available online.

Author Contributions: Investigation, I.A., C.T., J.E., G.S.-S.; data curation, I.A., C.T., G.S.-S.; writing—original draft preparation, I.A., C.T., J.E., G.S.-S.; writing-review and editing, I.A., C.T., J.E., G.S.-S.; funding acquisition, I.A. 
Funding: We thank the Ministerio de Ciencia e Innovación (Project No. CTQ2015-63997-C2-2-P) and the Comunidad Autónoma de Madrid (Project FOTOCARBON, ref S2013/MIT-2841) for continuous support.

Acknowledgments: Thanks are given to the CTI (CSIC), and to the Irish Centre for High-End Computing (ICHEC) for the provision of computational facilities.

Conflicts of Interest: The authors declare no conflict of interest.

\section{References}

1. Lehn, J.M. Supramolecular Chemistry Concepts and Perspectives; Wiley-VCH: Weinheim, Germany, 1995.

2. Müller-Dethlefs, K.; Hobza, P. Noncovalent Interactions: A Challenge for Experiment and Theory. Chem. Rev. 2000, 100, 143-168. [CrossRef] [PubMed]

3. Scheiner, S. Sensitivity of noncovalent bonds to intermolecular separation: Hydrogen, halogen, chalcogen, and pnicogen bonds. CrystEngComm 2013, 15, 3119-3124. [CrossRef]

4. Scheiner, S. The pnicogen bond: Its relation to hydrogen, halogen, and other noncovalent bonds. Acc. Chem. Res. 2013, 46, 280-288. [CrossRef] [PubMed]

5. Metrangolo, P.; Resnati, G.; Pilati, T.; Biella, S. Halogen Bonding: Fundamentals and Applications; Springer: Berlin, Germany, 2008.

6. Rozas, I.; Alkorta, I.; Elguero, J. Field effects on dihydrogen bonded systems. Chem. Phys. Lett. 1997, 275, 423-428. [CrossRef]

7. Rozas, I.; Alkorta, I.; Elguero, J. Inverse Hydrogen-Bonded Complexes. J. Phys. Chem. A 1997, 101, 4236-4244. [CrossRef]

8. Scheiner, S. Effects of substituents upon the P $\cdots \mathrm{N}$ noncovalent interaction: The limits of its strength. J. Phys. Chem. A 2011, 115, 11202-11209. [CrossRef] [PubMed]

9. Zahn, S.; Frank, R.; Hey-Hawkins, E.; Kirchner, B. Pnicogen bonds: A new molecular linker? Chem. Eur. J. 2011, 17, 6034-6038. [CrossRef]

10. Sundberg, M.R.; Uggla, R.; Viñas, C.; Teixidor, F.; Paavola, S.; Kivekäs, R. Nature of intramolecular interactions in hypercoordinate C-substituted 1,2-dicarba-closo-dodecaboranes with short P. . P distances. Inorg. Chem. Commun. 2007, 10, 713-716. [CrossRef]

11. Del Bene, J.E.; Alkorta, I.; Elguero, J.; Sánchez-Sanz, G. Lone-pair hole on P: P $\cdots$ N pnicogen bonds assisted by halogen bonds. J. Phys. Chem. A 2017, 121, 1362-1370. [CrossRef]

12. Sanchez-Sanz, G.; Trujillo, C.; Alkorta, I.; Elguero, J. Modulating intramolecular P ‥N pnictogen interactions. Phys. Chem. Chem. Phys. 2016, 18, 9148-9160. [CrossRef]

13. Trujillo, C.; Sanchez-Sanz, G.; Alkorta, I.; Elguero, J. Halogen, chalcogen and pnictogen interactions in $\left(\mathrm{XNO}_{2}\right)_{2}$ homodimers $(\mathrm{X}=\mathrm{F}, \mathrm{Cl}, \mathrm{Br}, \mathrm{I})$. New J. Chem. 2015, 39, 6791-6802. [CrossRef]

14. Sánchez-Sanz, G.; Trujillo, C.; Alkorta, I.; Elguero, J. Intermolecular weak interactions in HTeXH dimers (X=O, $\mathrm{S}, \mathrm{Se}, \mathrm{Te})$ : Hydrogen bonds, chalcogen-chalcogen contacts and chiral discrimination. Chem. Phys. Chem. 2012, 13, 496-503. [CrossRef] [PubMed]

15. Sánchez-Sanz, G.; Alkorta, I.; Elguero, J. Theoretical study of the HXYH dimers (X, Y = O, S, Se). Hydrogen bonding and chalcogen-chalcogen interactions. Mol. Phys. 2011, 109, 2543-2552. [CrossRef]

16. Azofra, L.; Alkorta, I.; Scheiner, S. Noncovalent interactions in dimers and trimers of $\mathrm{SO}_{3}$ and $\mathrm{CO}$. Theor. Chem. Acc. 2014, 133, 1-8. [CrossRef]

17. Sanz, P.; Yáñez, M.; Mó, O. Resonance-assisted intramolecular chalcogen-chalcogen interactions? Chem. Eur. J. 2003, 9, 4548-4555. [CrossRef]

18. Sánchez-Sanz, G.; Trujillo, C. Improvement of anion transport systems by modulation of chalcogen interactions: The influence of solvent. J. Phys. Chem. A 2018, 122, 1369-1377. [CrossRef] [PubMed]

19. Bauzá, A.; Mooibroek, T.J.; Frontera, A. Tetrel-bonding interaction: Rediscovered supramolecular force? Angew. Chem. Int. Ed. 2013, 52, 12317-12321. [CrossRef] [PubMed]

20. Varadwaj, P.R.; Varadwaj, A.; Jin, B.-Y. Significant evidence of C $\cdots$ O and C . C long-range contacts in several heterodimeric complexes of $\mathrm{CO}$ with $\mathrm{CH} 3-\mathrm{X}$, should one refer to them as carbon and dicarbon bonds! Phys. Chem. Chem. Phys. 2014, 16, 17238-17252. [CrossRef]

21. Legon, A.C. Tetrel, pnictogen and chalcogen bonds identified in the gas phase before they had names: A systematic look at non-covalent interactions. Phys. Chem. Chem. Phys. 2017, 19, 14884-14896. [CrossRef] 
22. Alkorta, I.; Rozas, I.; Elguero, J. Molecular complexes between silicon derivatives and electron-rich groups. J. Phys. Chem. A 2001, 105, 743-749. [CrossRef]

23. Bauzá, A.; Mooibroek, T.J.; Frontera, A. The bright future of unconventional $\sigma / \pi$-hole interactions. Chem. Phys. Chem. 2015, 16, 2496-2517.

24. Murray, J.S.; Lane, P.; Politzer, P. A predicted new type of directional noncovalent interaction. Int. J. Quantum Chem. 2007, 107, 2286-2292. [CrossRef]

25. Murray, J.; Concha, M.; Lane, P.; Hobza, P.; Politzer, P. Blue shifts vs. red shifts in $\sigma$-hole bonding. J. Mol. Model. 2008, 14, 699-704. [CrossRef]

26. Mohajeri, A.; Pakiari, A.H.; Bagheri, N. Theoretical studies on the nature of bonding in $\sigma$-hole complexes. Chem. Phys. Lett. 2009, 467, 393-397. [CrossRef]

27. Buckingham, A.D.; Fowler, P.W. A model for the geometries of Van der Waals complexes. Can. J. Chem. 1985, 63, 2018-2025. [CrossRef]

28. Legon, A.C.; Millen, D.J. Angular geometries and other properties of hydrogen-bonded dimers: A simple electrostatic interpretation of the success of the electron-pair model. Chem. Soc. Rev. 1987, 16, 467-498. [CrossRef]

29. Stone, A.J.; Price, S.L. Some new ideas in the theory of intermolecular forces: Anisotropic atom-atom potentials. J. Phys. Chem. 1988, 92, 3325-3335. [CrossRef]

30. Brinck, T.; Murray, J.S.; Politzer, P. Surface electrostatic potentials of halogenated methanes as indicators of directional intermolecular interactions. Int. J. Quantum Chem. 1992, 44, 57-64. [CrossRef]

31. Burling, F.T.; Goldstein, B.M. Computational studies of nonbonded sulfur-oxygen and selenium-oxygen interactions in the thiazole and selenazole nucleosides. J. Am. Chem. Soc. 1992, 114, 2313-2320. [CrossRef]

32. Price, S.L. Applications of realistic electrostatic modelling to molecules in complexes, solids and proteins. J. Chem. Soc. Faraday Trans. 1996, 92, 2997-3008. [CrossRef]

33. Auffinger, P.; Hays, F.A.; Westhof, E.; Ho, P.S. Halogen bonds in biological molecules. Proc. Natl. Acad. Sci. USA 2004, 101, 16789-16794. [CrossRef] [PubMed]

34. Awwadi, F.F.; Willett, R.D.; Peterson, K.A.; Twamley, B. The nature of Halogen $\cdots$ Halogen synthons: Crystallographic and theoretical studies. Chem. Eur. J. 2006, 12, 8952-8960. [CrossRef]

35. Politzer, P.; Riley, K.E.; Bulat, F.A.; Murray, J.S. Perspectives on halogen bonding and other $\sigma$-hole interactions: Lex parsimoniae (Occam's Razor). Comput. Theor. Chem. 2012, 998, 2-8. [CrossRef]

36. Hennemann, M.; Murray, J.; Politzer, P.; Riley, K.; Clark, T. Polarization-induced $\sigma$-holes and hydrogen bonding. J. Mol. Model. 2012, 18, 2461-2469. [CrossRef] [PubMed]

37. Clark, T. $\sigma$-Holes. WIREs Comput. Mol. Sci. 2013, 3, 13-20. [CrossRef]

38. Politzer, P.; Murray, J.S. Halogen bonding: An interim discussion. Chem. Phys. Chem. 2013, 14, $278-294$. [CrossRef]

39. Hunter, C.A.; Anderson, H.L. What is cooperativity? Angew. Chem. Int. Ed. 2009, 48, 7488-7499. [CrossRef] [PubMed]

40. Sun, J.; Riel, A.M.S.; Berryman, O.B. Solvatochromism and fluorescence response of a halogen bonding anion receptor. New J. Chem. 2018, 42, 10489-10492. [CrossRef] [PubMed]

41. Carlsson, A.-C.C.; Scholfield, M.R.; Rowe, R.K.; Ford, M.C.; Alexander, A.T.; Mehl, R.A.; Ho, P.S. Increasing enzyme stability and activity through hydrogen bond-enhanced halogen bonds. Biochemistry 2018, 57, 4135-4147. [CrossRef] [PubMed]

42. Ośmiałowski, B.; Kolehmainen, E.; Gawinecki, R.; Kauppinen, R.; Koivukorpi, J.; Valkonen, A. NMR and quantum chemical studies on association of 2,6-bis(acylamino)pyridines with selected imides and 2,2'-dipyridylamine. Struct. Chem. 2010, 21, 1061-1067. [CrossRef]

43. Lane, J.R.; Contreras-García, J.; Piquemal, J.-P.; Miller, B.J.; Kjaergaard, H.G. Are bond critical points really critical for hydrogen bonding? J. Chem. Theor. Comput. 2013, 9, 3263-3266. [CrossRef] [PubMed]

44. Jabłoński, M. Bond paths between distant atoms do not necessarily indicate dominant interactions. J. Comput. Chem. 2018, 39, 2183-2195. [CrossRef]

45. Espinosa, E.; Alkorta, I.; Elguero, J.; Molins, E. From weak to strong interactions: A comprehensive analysis of the topological and energetic properties of the electron density distribution involving $\mathrm{X}-\mathrm{H} \cdots \mathrm{F}-\mathrm{Y}$ systems. J. Chem. Phys. 2002, 117, 5529-5542. [CrossRef] 
46. Mata, I.; Alkorta, I.; Molins, E.; Espinosa, E. Universal features of the electron density distribution in hydrogen-bonding regions: A comprehensive study involving $\mathrm{H} \cdots \mathrm{X}(\mathrm{X}=\mathrm{H}, \mathrm{C}, \mathrm{N}, \mathrm{O}, \mathrm{F}, \mathrm{S}, \mathrm{Cl}, \pi)$ interactions. Chem. Eur. J. 2010, 16, 2442-2452. [CrossRef]

47. Alkorta, I.; Rozas, I.; Elguero, J. Charge-transfer complexes between dihalogen compounds and electron donors. J. Phys. Chem. A 1998, 102, 9278-9285. [CrossRef]

48. Del Bene, J.E.; Alkorta, I.; Sanchez-Sanz, G.; Elguero, J. Structures, energies, bonding, and NMR properties of pnicogen complexes $\mathrm{H}_{2} \mathrm{XP}: \mathrm{NXH}_{2}\left(\mathrm{X}=\mathrm{H}, \mathrm{CH}_{3}, \mathrm{NH}_{2}, \mathrm{OH}, \mathrm{F}, \mathrm{Cl}\right)$. J. Phys. Chem. A 2011, 115, 13724-13731. [CrossRef] [PubMed]

49. Alkorta, I.; Blanco, F.; Elguero, J.; Dobado, J.A.; Ferrer, S.M.; Vidal, I. Carbon ‥Carbon weak interactions. J. Phys. Chem. A 2009, 113, 8387-8393. [CrossRef]

50. Cremer, D.; Kraka, E. A Description of the Chemical Bond in Terms of Local Properties of Electron Density and Energy. Croatica Chem. Acta 1984, 57, 1259-1281.

51. Jenkins, S.; Morrison, I. The chemical character of the intermolecular bonds of seven phases of ice as revealed by ab initio calculation of electron densities. Chem. Phys. Lett. 2000, 317, 97-102. [CrossRef]

52. Aronld, W.D.; Oldfield, E. The chemical nature of hydrogen bonding in proteins via NMR: J-couplings, chemical shifts, and AIM theory. J. Am. Chem. Soc. 2000, 122, 12835-12841. [CrossRef]

53. Setiawan, D.; Kraka, E.; Cremer, D. Description of pnicogen bonding with the help of vibrational spectroscopy-The missing link between theory and experiment. Chem. Phys. Lett. 2014, 614, 136-142. [CrossRef]

54. Sánchez-Sanz, G.; Trujillo, C.; Alkorta, I.; Elguero, J. Theoretical study of cyanophosphines: Pnicogen vs. dipole-dipole interactions. Comput. Theor. Chem. 2015, 1053, 305-314. [CrossRef]

55. Sánchez-Sanz, G.; Trujillo, C.; Alkorta, I.; Elguero, J. Intramolecular pnicogen interactions in phosphorus and arsenic analogues of proton sponges. Phys. Chem. Chem. Phys. 2014, 16, 15900-15909. [CrossRef]

56. Sánchez-Sanz, G.; Alkorta, I.; Trujillo, C.; Elguero, J. Intramolecular pnicogen interactions in PHF- $\left(\mathrm{CH}_{2}\right)_{\mathrm{n}}$-PHF ( $\left.\mathrm{n}=2-6\right)$ systems. Chem. Phys. Chem. 2013, 14, 1656-1665. [CrossRef] [PubMed]

57. Sánchez-Sanz, G.; Trujillo, C.; Alkorta, I.; Elguero, J. Weak interactions between hypohalous acids and dimethylchalcogens. Phys. Chem. Chem. Phys. 2012, 14, 9880-9889. [CrossRef] [PubMed]

58. Sánchez-Sanz, G.; Trujillo, C.; Alkorta, I.; Elguero, J. Electron density shift description of non-bonding intramolecular interactions. Comput. Theor. Chem. 2012, 991, 124-133. [CrossRef]

59. Møller, C.; Plesset, M.S. Note on an approximation treatment for many-electron systems. Phys. Rev. 1934, 46, 618-622. [CrossRef]

60. Woon, D.E.; Dunning, T.H. Gaussian basis sets for use in correlated molecular calculations. V. Core-valence basis sets for boron through neon. J. Chem. Phys. 1995, 103, 4572-4585. [CrossRef]

61. Dunning, T.H. Gaussian-Basis Sets for Use in Correlated Molecular Calculations 1. The Atoms Boron through Neon and Hydrogen. J. Chem. Phys. 1989, 90, 1007-1023. [CrossRef]

62. Frisch, M.J.; Trucks, G.W.; Schlegel, H.B.; Scuseria, G.E.; Robb, M.A.; Cheeseman, J.R.; Scalmani, G.; Barone, V.; Mennucci, B.; Petersson, G.A.; et al. Gaussian 09, Revision B. 01; Gaussian, Inc.: Wallingford, CT, USA, 2009.

63. Halkier, A.; Helgaker, T.; Jørgensen, P.; Klopper, W.; Olsen, J. Basis-set convergence of the energy in molecular Hartree-Fock calculations. Chem. Phys. Lett. 1999, 302, 437-446. [CrossRef]

64. Halkier, A.; Klopper, W.; Helgaker, T.; Jørgensen, P.; Taylor, P.R. Basis set convergence of the interaction energy of hydrogen-bonded complexes. J. Chem. Phys. 1999, 111, 9157-9167. [CrossRef]

65. Bader, R.F.W. Atoms in Molecules. A Quantum Theory; Claredon Press: Oxford, UK, 1990.

66. Popelier, P.L.A. Atoms in Molecules. An Introduction; Prentice-Hall: Manchester, UK, 2000.

67. Keith, T.A. AIMAll (Version 15.05.18); TK Gristmill Software: Overland Park, KS, USA, 2015.

(C) 2019 by the authors. Licensee MDPI, Basel, Switzerland. This article is an open access article distributed under the terms and conditions of the Creative Commons Attribution (CC BY) license (http:// creativecommons.org/licenses/by/4.0/). 